\title{
Indirect Determination of Molecular Chlorine by Fourier Transform Infrared Spectrometry
}

\author{
ZOLTÁN BACSIK,* NÓRA BALOGH, and JÁNOS MINK \\ Institute of Structural Chemistry, Chemical Research Center, Hungarian Academy of Sciences, Pusztaszeri út 59-67, H-1025 Budapest, Hungary \\ (Z.B., J.M.); and Research Institute of Chemical and Process Engineering, University of Pannonia,Egyetem u. 10, H-8200 Veszprém, Hungary \\ $(N . B ., J . M$.
}

Index Headings: Fourier transform infrared spectroscopy; FT-IR spectroscopy; Gas analysis; Chlorine gas.

\section{INTRODUCTION}

Nowadays, Fourier transform infrared (FT-IR) spectrometry (both extractive and open-path techniques) is widely used for the detection of air pollutants ${ }^{1-6}$ because the method is fast, reliable, and nondestructive. It is capable of detecting simultaneously all compounds except non-infrared active homonuclear diatomic molecules.

Molecular chlorine gas has many anthropogenic sources, including water treatment plants, chemical production facilities, ceramic brick industries, and paper production processes, ${ }^{7-9}$ and it can also be formed in marine environments by reactions with sea salt particles. ${ }^{10-13}$ Various sensors have been applied to detect chlorine, including chemical sensors based on semiconductor metal oxides. ${ }^{14}$ Mass spectrometry also can be used for the determination of halogen molecules at atmospheric pressure. $^{10,15}$ A mist chamber and ion chromatographic detection has been employed to detect molecular chlorine indirectly at the parts per trillion (ppt) level. ${ }^{16}$ Spectroscopic techniques (e.g., ultraviolet (UV), Raman) are also capable of measuring molecular chlorine directly. An artificial chlorine cloud was investigated by Edner et al. ${ }^{17}$ by the differential absorption LIDAR (light detection and ranging) method.

Fourier transform infrared spectrometry has already been used to detect a homonuclear diatomic molecule. Larsen and co-workers ${ }^{18}$ measured the concentration of oxygen in a gas cell by determining the concentration of ozone produced upon UV irradiation of the sample. The authors established a linear correlation between the concentration of oxygen in the original sample and the concentration of ozone produced by photolysis of the sample. The aim of the present work was to investigate whether it is possible to detect chlorine molecules by means of FT-IR spectrometry as predicted by Hanst. ${ }^{19}$ If successful, a new analytical method can perhaps be developed based on this investigation.

\section{EXPERIMENTAL}

A Bio-Rad FTS-185 series spectrometer and a multipass gas cell (Infrared Analysis Inc., Anaheim, CA) with a 25.7-m effective path length were used for the experiments. The special cell was equipped with a mercury UV-radiation source, whereby ozone and reactive radicals can be produced. The source of the radiation was a medium-pressure quartz mercury

Received 19 June 2007; accepted 7 January 2008.

* Author to whom correspondence should be sent. E-mail: bacsik@ chemres.hu lamp. This type of lamp emits one or two percent of its radiation in the $185 \mathrm{~nm}$ mercury line and about $90 \%$ in the 254 $\mathrm{nm}$ line, with the remainder in lines that fall in the near-UV and visible ranges. The $185 \mathrm{~nm}$ photons dissociate oxygen molecules and the resultant oxygen atoms react mainly with molecular oxygen to form ozone. The ozone can react with other molecules, or it can absorb the $254 \mathrm{~nm}$ photons and be photo-dissociated, giving oxygen atoms in the energetic singlet-D state. These energetic atoms react with water to produce hydroxyl radicals. The ultraviolet photons can also directly photo-dissociate pollutant molecules. ${ }^{19}$

The concentration of molecular chlorine gas was measured with a wide-range vacuum gauge (Kurt Lesker Co, KJL902074) connected to a vacuum system. Following introduction of a known quantity of chlorine gas and normal air (according to the analysis of the infrared spectra, this air contained $6650 \mathrm{ppm}$ water vapor, $333 \mathrm{ppm}$ carbon dioxide, $1.77 \mathrm{ppm}$ methane, $0.32 \mathrm{ppm}$ nitrous oxide, and $0.30 \mathrm{ppm}$ carbon monoxide) at atmospheric pressure into the evacuated gas cell, the UV lamp was switched on after recording the first single beam spectrum. Next, a kinetic study was carried out during the photolysis: a spectrum was recorded every $15 \mathrm{~s}$.

\section{RESULTS AND DISCUSSION}

Since there are many possible reactions (e.g., Eqs. 1-5) beyond ozone and reactive radical formation under the influence of the UV lamp, it is not practical to try to explain everything that could occur in the gas cell. In the course of the reactions, chlorine will be produced in atomic form and serve as a catalyst for ozone depletion. Some possible reactions are given here: 20,21

$$
\begin{gathered}
\mathrm{CL}+\mathrm{O}_{3} \rightarrow \mathrm{ClO}+\mathrm{O}_{2} \\
\mathrm{OH}+\mathrm{O}_{3} \rightarrow \mathrm{HO}_{2}+\mathrm{O}_{2} \\
\mathrm{ClO}+\mathrm{HO}_{2} \rightarrow \mathrm{HOCl}+\mathrm{O}_{2} \\
\mathrm{HOCl}+h \mathrm{v} \rightarrow \mathrm{OH}+\mathrm{Cl} \\
\mathrm{Net} \mathrm{O}_{3}+\mathrm{O}_{3} \rightarrow \mathrm{O}_{2}+\mathrm{O}_{2}+\mathrm{O}_{2}
\end{gathered}
$$

The important point is that a band had to be identified that belongs to a molecule produced from the reaction of ozone or reactive radicals with molecular chlorine present in the sample gas. It was expected that the analytical band would be developed in a short time with an appropriate intensity and would not be overlapped with other bands in the spectra. From a preliminary investigation and bearing in mind the possible 


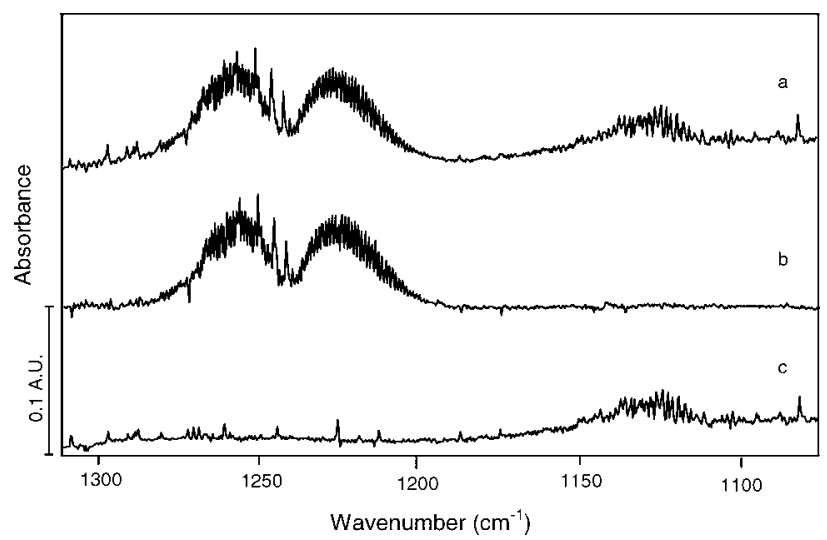

FIG. 1. Quantitative determination of hypochlorous acid. (a) Sample spectrum, (b) $\mathrm{HOCl}$ reference, and (c) sample spectrum after subtraction of $\mathrm{HOCl}$ reference.

reactions, the deformation mode of hypochlorous acid $(\mathrm{HOCl})$ at $1239 \mathrm{~cm}^{-1}$ should be suitable for this purpose (Fig. 1).

A reference spectrum of $\mathrm{HOCl}$ was constructed from an absorbance spectrum of the sample, cutting out the spectral range of $1080-1320 \mathrm{~cm}^{-1}$. The shape of the $\mathrm{HOCl}$ band in this reference spectrum was checked by an artificial reference spectrum of $\mathrm{HOCl}$ made with the aid of software ${ }^{22}$ using data from the HITRAN ${ }^{23}$ database. The $\mathrm{HOCl}$ reference spectrum was subtracted from all the spectra measured during the photolysis and subtraction factors were plotted as a function of time. Linear trends were fitted to the first five points (Fig. 2). Sample spectra were recorded three times (three independent measurements of the chlorine concentrations with the vacuum gauge) for each point in the calibration. The measurements were fairly reproducible (see error bars in Fig. 3).

Plotting the calibration chlorine concentrations as a function of the gradients of the lines of $\mathrm{HOCl}$ concentration changes (the factual concentrations of $\mathrm{HOCl}$ were not determined, but the subtraction factors are directly proportional to the concentrations according to the Lambert-Beer law in this absorbance range), a linear relationship (Fig. 3) was established for the concentration range investigated (Eq. 6).

$$
c_{\text {chlorine }}=1190.7 b-3.248, \quad\left(R^{2}=0.989\right)
$$

where $c_{\text {chlorine }}$ is concentration of chlorine (ppmv) and $b$ is the gradient of the $\mathrm{HOCl}$ concentration change.

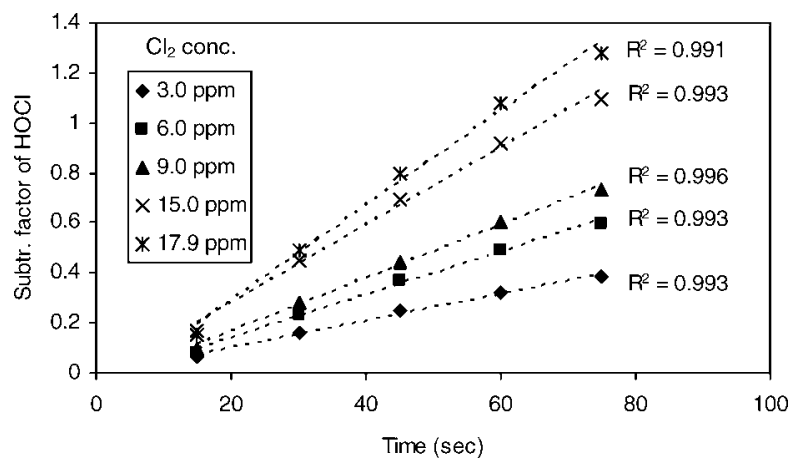

FIG. 2. Changes in $\mathrm{HOCl}$ subtraction factors (concentrations) during the first $75 \mathrm{~s}$ of the photolysis at different chlorine calibration concentrations.

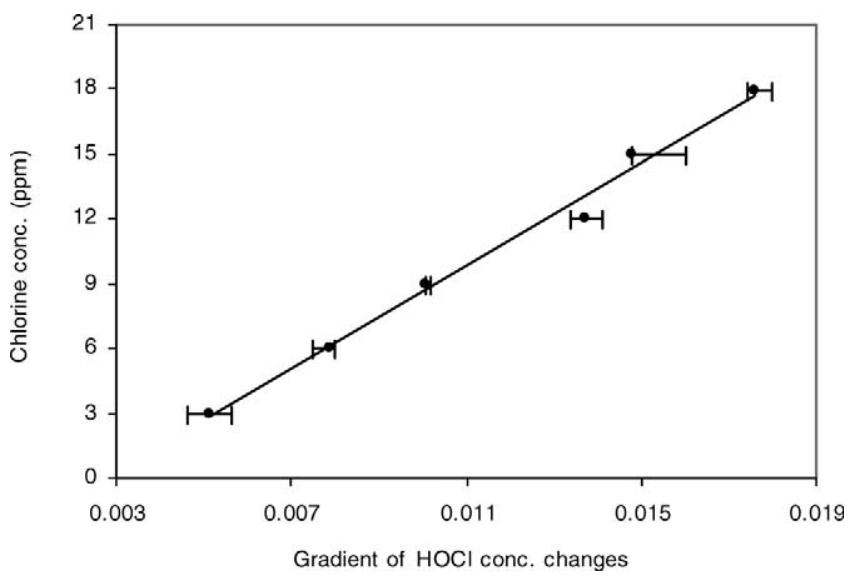

FIG. 3. Calibration chlorine concentrations as a function of the gradients of the lines of $\mathrm{HOCl}$ concentration changes. The error bars represent the minimal and maximal gradients determined from $\mathrm{HOCl}$ concentrations measured during the three independent experiments.

TABLE I. Calculated and measured (with the vacuum gauge) chlorine concentrations and the error of the developed method.

\begin{tabular}{ccccc}
\hline $\begin{array}{c}\text { Gradient of } \\
\text { the HOCl } \\
\begin{array}{c}\text { concentration } \\
\text { change }\end{array}\end{array}$ & $\begin{array}{c}\text { Chlorine } \\
\text { concentration } \\
\text { determined from } \\
\text { Eq. 6 (ppmv) }\end{array}$ & $\begin{array}{c}\text { Measured } \\
\text { chlorine } \\
\text { concentration } \\
\text { (ppmv) }\end{array}$ & Difference & $\begin{array}{c}\text { Relative } \\
\text { error (\%) }\end{array}$ \\
\hline 0.0051 & 2.83 & 2.99 & 0.16 & 5.35 \\
0.0079 & 6.16 & 5.98 & 0.18 & 3.01 \\
0.0100 & 8.66 & 8.97 & 0.31 & 3.45 \\
0.0137 & 13.06 & 11.96 & 1.10 & 9.19 \\
0.0148 & 14.38 & 14.95 & 0.57 & 3.81 \\
0.0176 & 17.71 & 17.94 & 0.23 & 1.28 \\
\hline
\end{tabular}

\section{CONCLUSION}

By monitoring the concentration of $\mathrm{HOCl}$, clear evidence was obtained for a correspondence with the original chlorine concentration in the gas cell. According to our investigation, unknown chlorine concentrations can be determined from the gradient of concentration change of the $\mathrm{HOCl}$ produced during the course of the photolysis reaction in the range of about 3-18 ppm, with an acceptable level of relative error (Table I). It has been shown that analysis of molecular chlorine by means of FT-IR spectrometry is therefore theoretically possible.

Our future work will be focused on an investigation of the applicability of the method over a wider concentration range and we will work out the exact chemometrics for measurement of molecular chlorine with analytical accuracy. It will also be important to investigate the influence of water (as a possible source of hydrogen for $\mathrm{HOCl}$ ) and other compounds present in the sample gas and produced during the photolysis on the original chlorine concentration. ${ }^{24-27}$

\section{ACKNOWLEDGMENTS}

The authors thank Ian S. Butler (McGill University, Montreal, Canada) for his assistance in the preparation of this paper.

1. G. M. Russwurm and J. W. Childers, "Open-path Fourier Transform Infrared Spectroscopy", in Handbook of Vibrational Spectroscopy, J. M. Chalmers and P. R. Griffiths, Eds. (John Wiley and Sons, New York, 2002), vol. 2, pp. 1750-1773.

2. R. L. Spellicy and J. D. Webb, "Atmospheric Monitoring Using Extractive 
Techniques", in Handbook of Vibrational Spectroscopy, J. M. Chalmers and P. R. Griffiths, Eds. (John Wiley and Sons, New York, 2002), vol. 2, pp. 1721-1749.

3. D. W. T. Griffith and I. M. Jamie, "Fourier Transform Infrared Spectrometry in Atmospheric and Trace Gas Analysis", in Encyclopedia of Analytical Chemistry, R. A. Meyers, Ed. (John Wiley and Sons, Chichester, 2000), pp. 1979-2007.

4. Z. Bacsik, J. Mink, and G. Keresztury, Appl. Spectrosc. Rev. 39, 295 (2004).

5. Z. Bacsik, J. Mink, and G. Keresztury, Appl. Spectrosc. Rev. 40, 327 (2005).

6. Z. Bacsik, V. Komlósi, T. Ollár, and J. Mink, Appl. Spectrosc. Rev. 41, 77 (2006).

7. P. L. Tanaka, S. Oldfield, J. D. Neece, C. B. Mullins, and D. T. Allen, Environ. Sci. Technol. 34, 4470 (2000).

8. E. Galan, I. Gonzalez, and B. Fabbri, Atmos. Environ. 36, 5289 (2002).

9. O. Hov, Atmos. Environ. 19, 471 (1985).

10. C. W. Spicer, E. G. Chapman, B. J. Finlayson-Pitts, R. A. Plastridge, J. M. Hubbe, J. D. Fast, and C. M. Berkowitz, Nature (London) 394, 353 (1998).

11. K. W. Oum, M. J. Lakin, D. O. DeHaan, T. Brauers, and B. J. FinlaysonPitts, Science (Washington, D.C.) 279, 74 (1998).

12. C. W. Spicer, R. A. Plastridge, K. L. Foster, B. J. Finlayson-Pitts, J. W. Bottenheim, A. M. Grannas, and P. B. Shepson, Atmos. Environ. 36, 2721 (2002).

13. B. D. Finley and E. S. Saltzman, Geophys. Res. Lett. 33 Art. No. L11809 (2006).

14. E. E. Gutman, Sens. Actuators, B: Chem. 23, 209 (1995).

15. M. M. Ivey and K. L. Foster, Anal. Chem. 77, 1467 (2005).

16. W. C. Keene, J. R. Maben, A. A. P. Pszenny, and J. N. Galloway, Environ. Sci. Technol. 27, 866 (1993).
17. H. Edner, K. Fredriksson, A. Sunesson, and W. Wendt, Appl. Opt. 26, 3183 (1987).

18. E. S. Larsen and M. L. Spartz, Mikrochim. Acta [Suppl.] 14, 555 (1997).

19. P. L. Hanst, "Photolysis Assisted Pollution Analysis (PAPA)", in Measurement of Toxic and Related Air Pollutants (Proceedings of the 1994 US EPA/AWMA International Symposium, Durham, NC, May 2-6, 1994), pp. 576-582.

20. M. J. Molina and F. S. Rowland, Nature (London) 249, 810 (1974).

21. R. P. Wayne, Chemistry of Atmospheres (Clarendon Press, Oxford, 1991), pp. 160-163.

22. Institute of Atmospheric Optics of Siberian Branch of the Russian Academy of Science, Tomsk, The Information System Spectroscopy of Atmospheric Gases (Web-based software for modeling and visualising molecular absorption spectra), http://spectra.iao.ru/en.

23. L. S. Rothman, A. Barbe, D. Chris Benner, L. R. Brown, C. Camy-Peyret, M. R. Carleer, K. Chance, C. Clerbaux, V. Dana, V. M. Devi, A. Fayt, J.-M. Flaud, R. R. Gamache, A. Goldman, D. Jacquemart, K. W. Jucks, W. J. Lafferty, J.-Y. Mandin, S. T. Massie, V. Nemtchinov, D. A. Newnham, A. Perrin, C. P. Rinsland, J. Schroeder, K. M. Smith, M. A. H. Smith, K. Tang, R. A. Toth, J. Vander Auwera, P. Varanasi, and K. Yoshino, J. Quant. Spectrosc. Radiat. Transfer 82, 5 (2003).

24. M. G. Bryukov, V. D. Knyazev, S. M. Lomnicki, C. A. McFerrin, and B. Dellinger, J. Phys. Chem. A 108, 10464 (2004).

25. M. J. Ezell, W. H. Wang, A. A. Ezell, G. Soskin, and B. J. Finlayson-Pitts, Phys. Chem. Chem. Phys. 4, 5813 (2002).

26. L. Wang, J. Arey, and R. Atkinson, Environ. Sci. Technol. 39, 5302 (2005).

27. M. J. Molina, Pure Appl. Chem. 68, 1749 (1996). 